Dicenda. Estudios de lengua y literatura españolas

ISSN-e: $1988-2556$

http://dx.doi.org/10.5209/DICE.62140

\title{
Los afanes de amores o las máscaras del discurso decimonónico de la Reconquista en las orientales de José Zorrilla
}

\author{
Ronald Campos López ${ }^{1}$
}

Recibido: 30 de junio de 2016 / Aceptado: 31 de mayo de 2017

Resumen. En este artículo se analizan las ocho estrategias que permiten enmascarar tras el tema amoroso el discurso decimonónico de la Reconquista en las seis orientales de José Zorrilla. Se observa cómo estos poemas participan mayormente de la conciencia cívica conservadora de su autor, contribuyendo con la representación imaginaria y colectiva de la identidad nacional española, durante la primera mitad del siglo XIX. La idealización de la mujer amada, la sensorialidad y sensualidad, y el exotismo enmascaran un sentido patriótico fundado en el medievalismo romántico, el colonialismo español, el concepto de raza, las sociedades de frontera, la soberanía imperial española, la lengua castellana, el régimen diurno de la imaginación simbólica; el uso de figuras arquetípicas, históricas, del romancero morisco, míticas y estereotípicas; la ambigüedad literaria; el uso estilístico de figuras descriptivas, patéticas y tropos; así como los tópicos cortesanos de la superioridad de la amada, el rechazo del amado y la albada. Pese al tradicionalismo de Zorrilla, en su sexta oriental se inscribe su voz liberal, proponiendo una nueva concepción de amor romántico, criticando la desvirtuación de la historia en función de la política nacionalista y subvirtiendo el sistema hegemónico, su oficialidad y represión.

Palabras clave: Poesía española; José Zorrilla; orientales; Reconquista; enmascaramiento.

\section{[en] The eagerness of love or the masks of the nineteenth century discourse of Reconquista in Jose Zorrilla orientals}

\begin{abstract}
This article analyzes the eight strategies that allow masking the nineteenth century discourse of Reconquista, behind loves themes, in the six oriental of Jose Zorrilla. These poems mostly participate in the civic and conservative awareness of Zorrilla. It contributes with imaginary and collective representation of Spanish national identity, in the first half of $19^{\text {th }}$ Century. The idealized image of women, sensoriality and sensuality, and the exoticism enable to mask a patriotic sense. It is based on the romantic medievalism, Spanish colonialism, race concept, border societies, Spanish imperial sovereignty, Castilian language, diurnal regimen of symbolic imagination; using of archetypical, historic, mythic, stereotypical and from Moorish Romance figures; stylistic using of descriptive and pathetic figures and tropes; as well as courtly topics of superiority of the love one, rejection of lover and dawn. Despite Zorrilla traditionalism, his liberal voice is heard on the sixth oriental. It proposes a new romantic love concept which, on one hand, criticizes the History distortion according to nationalistic policy and, on the other hand, subverts the hegemonic system, its official recognition and repression.
\end{abstract}

Keywords: Spanish poetry; Jose Zorrilla; oriental; Reconquista; masking.

1 Profesor de la Escuela de Filología, Lingüística y Literatura de la Universidad de Costa Rica. roncalo1125@gmail.com 
Sumario: 1. Contexto inicial; 2. ¡Afanes de amores?; 2.1. La puesta a prueba; 2.2. El hombre bipartito; 2.3. Las huellas colonialistas; 2.4. La raza endiosada; 2.5. Los límites en retroceso; 2.6. La insistencia en el padre; 2.7. Un asunto de lenguas; 2.8. Otras máscaras culturales; 2.8.1. Las fiestas de los toros; 2.8.2. La prueba del vestido; 2.8.3. La arquitectura cristiana; 2.8.4. Las artes y ciencias de Occidente; 3. La voz enmascarada de la Reconquista.

Cómo citar: Campos López, R. (2018). Los afanes de amores o las máscaras del discurso decimonónico de la Reconquista en las orientales de José Zorrilla, en Dicenda. Estudios de Lengua y Literatura Españolas, 36, 115-141.

\section{Contexto inicial}

Alborg (1980) lo insinuó, pero Navas Ruiz lo demostró: José Zorrilla fue, en parte por su relación con su padre, "un liberal de corazón y un conservador a la fuerza. [...] Como conservador, tuvo que exaltar el amor hacia un pasado y una religión que cada vez eran más criticados, pero que no dejaban de ser esencia de España. Como liberal, pudo ver los fallos de ese pasado y proponer soluciones modernizadoras" (Alborg, 1991: 126). La crítica, sin embargo, ha ignorado sistemáticamente al Zorrilla liberal y exaltado al tradicional.

Desde su tradicionalismo, Zorrilla compuso para multitudes, prefiriendo dos temas: la religión y la patria. Con base en estos, alteró -sin preocuparse- fantasiosamente la verdad histórica, para evocar un pasado español legendario, heroico y glorioso; así como una tradición católica, creencias y actitudes religiosas popularmente arraigadas. Por su españolidad, religión, musicalidad y sugestión personal, Zorrilla se convirtió en una notoria figura pública (Valera, 1902; Eguía Ruiz, 1917; Ibáñez, 1920; Barja, 1924; Rodríguez Lesmes, 1944; Menéndez Pidal, 1945; Sainz de Robles, 1950; Carrasco Urgoiti, 1956; Hatamleh, 1972; Navas Ruiz, 1973; Alborg, 1980; Lloréns, 1989).

Aunque Ibáñez (1920) afirmó que la poesía de Zorrilla no es política ni social, es evidente que, valiéndose del catolicismo y el concepto de patria, el vallisoletano manifestó una conciencia cívica (Navas Ruiz, 1973; Alborg, 1980). Pero, ¿por qué?

Con la Guerra de Independencia (1808-1814), España se enfrentó a las fuerzas napoleónicas y pasó al constitucionalismo. La Constitución de Cádiz (1812) derribó el dogmatismo teológico - la metafísica escolástica, la filosofía tradicional españolaante las nuevas orientaciones del pensamiento científico ilustrado. En consecuencia, la moral cristiana, sus devociones y fanatismos se relajaron. No obstante, Fernando VII abolió en 1814 la Constitución de Cádiz y, después del Trienio Liberal (18201823), no restituyó la Inquisición y permitió reformas liberales. En consecuencia, el enfrentamiento entre absolutistas y liberales derivó en la Primera Guerra Carlista (1833-1840). En este contexto, Zorrilla pidió la unidad de los españoles para mostrar al extranjero un frente común que ganara el respeto y la consideración internacional (Alborg, 1980). De ahí que se sirviera del sentimiento patriótico surgido durante las guerras napoleónicas; se nutriera de la visión romántica de la tradición y la Edad Media, en los cuales se encontraban la época heroica de España y su misticismo. Así pues, la conciencia cívica en la poesía de Zorrilla llegó a dialogar con las incipientes bases del discurso decimonónico de la Reconquista.

Como tal, el concepto de Reconquista nació y creció con ideología nacionalista. Aunque se consolidó en la historiografía hispánica durante la segunda mitad del 
XIX, desde el principio se asoció a la formación de la identidad nacional de España, asegurando una empresa y pasado comunes a todas las regiones del país y ofreciendo, simultáneamente, una singularidad esencial ante otras naciones europeas (García Fitz, 2009). Como período histórico (siglos VII-XV), la Reconquista constituyó un proyecto militar, económico e ideológicamente deliberado para desalojar a los musulmanes de la península ibérica (García de Cortázar, 1990). Se debió en principio a causas jurídicas y territoriales, no a diferencia de credos; pero en la Edad Media un argumento jurídico funcionaba de base para sustentar uno religioso. Por eso, la Reconquista se asumió como una actividad justificada y legal (guerra justa) y una acción deseable, meritoria, piadosa y santificada (guerra santa), con el propósito de recuperar el solar patrio, restaurar eclesiásticamente el culto cristiano y conformar sociedades de frontera. El concepto de Reconquista, por ende, terminó irrumpiendo con exitosa carga nacionalista, romántica y, en ocasiones, colonialista, hasta convertirse en uno de los principales mitos originarios del nacionalismo español en los siglos XIX y XX (García Fitz, 2009).

Igual que en la Edad Media, se asistió durante la primera mitad del siglo XIX a un contexto de divisiones políticas, en el que el discurso de la Reconquista supuso la unidad nacional con base en un cristianismo militante y la noción de patria. En esta coyuntura, Zorrilla escribió un corpus singular dentro de su poesía lírica inicial (anterior a 1852). Se trata de los seis poemas independientes titulados "Oriental", publicados los tres primeros en el tomo I (1837); el cuarto, en el tomo II (1838) y el quinto, en el tomo V (1839) de Poesías; mientras el sexto, en Recuerdos y fantasías (1844).

Para efectos de este análisis, se llama primera "Oriental" [O1] a la que inicia con el verso "Dueña de la negra toca"; segunda [O2] a la de "Corriendo van por la vega"; tercera [O3] a la de "Mañana voy, nazarena"; cuarta [O4] cuyo primer verso es "De la luna a los reflejos"; quinta [O5] a la de "Larga y pesada es la noche"; y sexta [O6] a la de "Escucha, hermosa cristiana".

Las seis orientales han sido reeditadas en las obras completas de Zorrilla (1850, 1852, 1905, 1943) y la antología de Mozos (Zorrilla, 1993b), aunque en esta última O5 está incompleta (faltan la palabra "vela" en el verso 55 y las dos últimas estrofas). Fuente Ballesteros (Zorrilla, 1993a) solo publicó las primeras cinco; Cossío (Zorrilla, 1946), las primeras cuatro ${ }^{2}$; Torres Nebreda (Zorrilla, 1984), la segunda, cuarta y sexta; Blecua (1951), Díaz Larios (1977) y Díez y Díez (2005) únicamente, la segunda. Se prescinde de las seis en antologías y colecciones significativas sobre Zorrilla $(1894,1917 a, 1917 b, 1925,1965)$ o la poesía romántica del XIX (Peña, 1984; Dobrian, 1988). Frente al drama y la leyenda, la lírica es la parte de la obra zorrillesca menos apreciada por la crítica, pese a su riqueza de registros (Cossío, 1946; Navas Ruiz, 1973; Fuentes Ballesteros, 1993). La atención sobre ella decreció entre 1893 y 1922. Vallejo y Ojeda (1994) señalan que se debió a no estar de moda por saturación, en especial después de la muerte de Zorrilla; por olvido o falta de reconocimiento de las virtudes del autor a quien todavía no se consideraba desde la perspectiva histórica. Sin embargo, algunos estudios se dieron entre 1923 y 1932; aun así, disminuyeron igualmente entre 1933 y 1942, a pesar de que en esta última década hubo una recuperación editorial por su obra dramática. Con todo, se mantuvo y ha mantenido una publicación regular de pocos poemas en antologías (Vallejo y

Cossío publica una quinta "Oriental”, pero se trata del fragmento VII del libro octavo de Granada. 
Ojeda, 1994). Quizá esta tendencia explique la ausencia de las orientales en las anteriores obras y otras.

Sin ir más allá de unas líneas, se ha dicho que las orientales son un grupo de poemas épicos de amor entre moros y cristianos; recrean ambientes pintorescos y remiten al mundo nazarí, sus harenes y otros temas moriscos; imitan de Víctor Hugo el tema oriental; o bien se las menciona apenas como preámbulo para hablar ampliamente del orientalismo de Zorrilla en Granada (Ibáñez, 1920; Zorrilla, 1943; Blecua, 1951; Dobrian, 1988; Fuentes Ballesteros, 1993; Díez y Díez, 2005). Con profundidad, solo se encuentran los análisis de Carrasco Urgoiti (1956), Hatamleh (1972) y Sebold (1993).

Carrasco Urgoiti (1956) analiza las seis orientales y observa la adopción por parte de Zorrilla de términos y procedimientos estilísticos de Víctor Hugo, pero sin acrecentar como este el vocabulario poético, aunque sí amoldando sus préstamos al Oriente arábigo-español. Sobre el tema granadino, señala la adscripción de tópicos nuevos: enumerar encantos de palacios, ciudades y jardines, los placeres de una vida muelle, la descripción pormenorizada de la belleza femenina, el deseo de libertad de la mujer de harén y un repertorio de epítetos orientalistas. Apunta que Zorrilla conservó recursos estilísticos del género morisco (mención de festejos, galas guerreras, ritmo octosilábico), alternándolas con nuevas y artificiosas formas métricas. Por esta pintoresca combinación, ubica a Zorrilla en mitad del camino entre el clima morisco tradicional y el orientalismo complejo de Víctor Hugo.

Hatamleh (1972) observa en O1 y O2 el camino e imaginación de Zorrilla en relación con la España musulmana. Con respecto a $\mathrm{O} 1$, analiza la historia del protagonista, la riqueza de metáforas, los anacronismos históricos como resultado de la misma libertad característica del romanticismo; la relación intertextual con "Odes et ballades", de Víctor Hugo, en cuanto a la enumeración de objetos valiosos y exóticos. Sobre O2 afirma que es la más característicamente oriental de todo el conjunto, pues en ella se encuentra la serie de variantes que gira en torno al romanticismo español; por eso, describe la historia del capitán, el tono del poema, su ritmo, algunas fuentes (crónicas históricas y el romancero popular castellano) de donde proceden algunos rasgos de este texto, la valoración de Granada debido a su sentir nacionalista, el paisaje de la Alhambra en consonancia con la hermosura de la cristiana, la comparación entre las tierras cristianas y musulmanas; la presencia del amor udrí en la actitud, sentimientos y amor platónico del capitán. Hatamleh asimismo analiza tres orientales más. Ejemplifica con $\mathrm{O} 3$ la preferencia de Zorrilla por la queja del musulmán despreciado; relaciona intertextualmente sus estrofas 6 y 7 con unos versos del poeta hispano-omeya al-Sarif al Taliq, donde se compara a la amada con la luna; advierte, finalmente, el conocimiento de Zorrilla respecto del dogma islámico, gracias a sus estudios del Corán. En cuanto a O4, se refiere al problema de la libertad de la mujer musulmana. En O6 considera el destino trágico del caballero musulmán.

Sebold (1993) enfatiza que las orientales tanto de Zorrilla y como las de Juan Arolas enlazan el orientalismo español de los siglos XVIII y XIX: un orientalismo que se venía manifestando a través de textos dramáticos, líricos, narrativos e históricos de José Cadalso, Nicolás Fernández de Moratín, Cándido María Trigueros, Tomás Antonio Sánchez, Pedro Montengón, Nicasio Álvarez de Cienfuegos y José Antonio Conde. Sebold destaca estos precedentes literarios, a fin de contrariar la señalada deuda que el orientalismo español tiene con el orienta- 
lismo hugoniano. Asimismo, describe algunos rasgos estructurales de las cinco primeras orientales (tipos de estrofas, cuadros); así como la repetición de diera o dime, rasgo estilístico que $\mathrm{O} 1$ y $\mathrm{O} 5$ recogen del cancionero popular. Ratifica la poetización de ambientes hispano-árabes como jardines y palacios, y el amor como único tema.

Partiendo, por tanto, de la poca e irregular atención de los editores y los aportes críticos existentes hasta el momento, se procede a resaltar el valor de las orientales de Zorrilla, analizando los enmascaramientos del discurso de la Reconquista, detrás de los afanes románticos por alcanzar algo más que a la mujer amada. Para el siguiente análisis hermenéutico, se utilizan los textos presentados por Alonso Cortés en su edición, pues en ella se revisa casi la totalidad de la obra de Zorrilla (1943).

\section{2) ¿Afanes de amores?}

La oriental es un género literario cuyo ambiente, personajes y motivos se relacionan con Oriente Extremo, Próximo o bien hispano-musulmán. Con Les Orientales, Víctor Hugo creó y cultivó dicho género en 1829. Sus textos fueron referente tanto para la escuela pintoresca del parnasianismo francés (Mortelette, 2005), como para Arolas y Zorrilla, los dos poetas que naturalizaron en España en 1837 las orientales con referencias a la historia de la Reconquista (Navas Ruiz, 1973; Lloréns, 1989; Sebold, 1993). En Zorrilla particularmente influyeron la idea de Oriente según los literatos europeos y las traducciones de la poesía árabe clásica (Sadiq, 1996).

Del romanticismo predominan en las orientales zorrillescas la idealización de la mujer amada, la sensorialidad y sensualidad, y principalmente el exotismo. Como se observa en estos poemas, la atracción exótica llevó a Zorrilla a interesarse por Oriente Próximo (India, Grecia, Túnez) y el oriente en casa (Granada, Córdoba y Sevilla). Tomó de civilizaciones exóticas rasgos de mentalidades y costumbres distintas para crear mundos poéticos, a medida que se interesaba por el oriente hispano-musulmán, ya que este formaba parte del pasado español y complementaba la visión medieval cristiana de España (Carrasco Urgoiti, 1956; Cabo Aseguinolaza, 2012). Con base en lo oriental, compuso escenas lírico-épicas pintorescas, donde la sensualidad y sensorialidad de las metáforas elevan la emotividad de la fuerza expresiva (Valera, 1902; Ibáñez, 1920; Hatamleh, 1972; Navas Ruiz, 1973), a fin de diferenciar entre Oriente y Occidente, y establecer un alejamiento no solo en el tiempo y el espacio, sino también del tiempo y el espacio que al discurso de la Reconquista le interesaba contar. Por eso, la raíz del acercamiento de Zorrilla a lo oriental hispano-musulmán se encuentra, justamente, en su españolismo, pues lo islámico -conocido y extraño a la vez- se oponía a la cristiandad y lo occidental (Carrasco Urgoiti, 1956; Dobrian, 1988). En el caso de Zorrilla, el exotismo no constituyó un simple escapismo, fábrica de clichés y baratijas. El exotismo español a lo largo del siglo XIX se configuró en oposición a la sociedad moderna y, por eso, reaccionó al progreso deshumanizador de la civilización occidental (Celma, 1989). De ahí que Zorrilla valorara el pasado andalusí, los últimos años de la dominación musulmana, el arranque de las nuevas empresas y grandezas imperiales, y los convirtiera no tanto en patria de poesía, sino en poesía de patria. Las características del romanticismo presentes en las orientales de Zorrilla, por tanto, se conjugan para enmascarar otro rasgo de este movimiento: el sentido patriótico. ¿Cómo? Al menos mediante ocho estrategias. 


\subsection{La puesta a prueba}

Hay una constante puesta a prueba de parte del sujeto lírico de O1, el capitán gomel de $\mathrm{O} 2$ y el caballero cordobés de $\mathrm{O} 3$ cuando insisten en llamar "sultana" a la cristiana amada. Esto no es sino su pretensión de que ella se convierta al islam: "Ven a Córdoba, cristiana,/ sultana serás allí,/ y el sultán será, ¡oh sultana!,/ un esclavo para ti. [...] Sultana serás si quieres,/ que, desiertos mis salones,/ está mi harén sin mujeres [...] sultana, a Córdoba voy" (Zorrilla, 1943: 37, 48 y 60). Para persuadirla, el sultán cordobés de quien se habla en $\mathrm{O} 1$ y el capitán de $\mathrm{O} 2$ le ofrecen, respectivamente, tales riquezas:

Diera la lanza mejor del Zenete más bizarro, y con su fresco verdor toda una orilla del Darro. Diera las fiestas de toros, y si fueran en sus manos, con las zambras de los moros el valor de los cristianos. Diera alfombras orientales, $\mathrm{y}$ armaduras, y pebetes, y diera..., ique tanto vales!, hasta cuarenta jinetes.

\section{$[\ldots]$}

Te dará tanta riqueza, tanta gala tunecina, que has de juzgar tu belleza para pagarle, mezquina.

\section{$[\ldots]$}

Yo te daré terciopelos y perfumes orientales, de Grecia te traeré velos, y de Cachemira chales. Yo te daré blancas plumas para que adornes tu frente, más blancas que las espumas de nuestros mares de oriente; y perlas para el cabello, y baños para el calor, y collares para el cuello, para los labios... jamor! - (Zorrilla, 1943: 37 y 48)

Aun con esta enumeración de regalos, ni la doncella $(\mathrm{O} 1)$ ni la cautiva cristiana (O2) acceden. Ellas no sucumben a las riquezas ni vida ostentosa, sensual y erótica 
ofrecida por lo musulmán. La ostentación no es importante para una auténtica cristiana: antes que los materiales, están los bienes morales y culturales ("—¿Qué me valen tus riquezas,/ respondióle la cristiana,/ si me quitas a mi padre,/ mis amigos y mis damas?", Zorrilla, 1943: 48). Al ofrecimiento y fortuna musulmanes se opone el ideal cristiano de sobriedad, recato, austeridad pública y personal que debe cumplir la mujer (1 Timoteo 2: 9-10). Estas damas, por tanto, materializan los nobles ideales cristianos. Por eso, en $\mathrm{O} 2$ y O3, la figura femenina alecciona moralmente sobre estos ideales.

Sin embargo, la prueba no acaba. Y el capitán gomel (O2), el caballero cordobés (O3) y el caballero moro (O6) insisten ahora en llamar "hourí" a la cautiva, la dama o la noble cristiana. Mediante el apóstrofe ("hourí del Edén, no llores", "Adiós, hourí idolatrada/ del corazón africano", Zorrilla, 1943: 48 y 449), trasladan al imaginario islámico la figura romántica de la mujer ángel, que tiende a responder al imaginario cristiano.

Ábrase aquí un paréntesis sobre un hallazgo novedoso. Ningún crítico se había percatado hasta el momento de que los versos "Adiós, hourí idolatrada/ del corazón africano" aparecen cambiados en la edición de 1905 por "Adiós, hurí seductora, rosa de pensil cristiano". Aunque se la llama "hourí", el segundo verso de esta sustitución devuelve la figura de la mujer ángel al terreno cristiano que dentro del poema y del romanticismo español le corresponde. ¿Será esta la causa del reemplazo o, simplemente, se busca corregir con esta variante la arbitrariedad de Zorrilla en la rima consonante en esta copla ${ }^{3}$, ya que en vez de XBAABA debería ser $\mathrm{ABAABA}^{4}$ ? Con todo, ¿quién realizó este cambio? ¿Acaso el editor: Manuel Pedro Delgado? Si así fue, ¿por qué no dejó constancia de él? Alonso Cortés (Zorrilla, 1943) afirmó que la edición de Delgado reprodujo, aunque mermadas, las obras completas que Zorrilla revisó y publicó en París en 1847 y 1852. Dice que son iguales. Por tanto, Alonso Cortés no percibió el cambio. Al final, revisando la obra de Zorrilla, queda claro que este cambio no se trata de un traslado de versos ni de una reelaboración por compromiso, dos fenómenos habituales en la forma de crear de este poeta. Fin del paréntesis.

Recobrando el hilo, cuando el capitán gomel, el caballero cordobés y el caballero moro llaman "hourí" a su amada, apelan a su belleza y virginidad, porque ella parece la ideal prometida por el Corán. Solo junto a ella alcanzarán el Ŷānna o Paraíso, donde se hallan la felicidad absoluta y vida eterna, a las que únicamente los musulmanes dignos y limpios de pecado podrán acceder: "Ha prometido Mahoma/ un paraíso, una hurí.../ tú habrás de ser ángel, sí,/ en esa región de aroma,/ y hemos de amarnos all'1" (Zorrilla, 1943: 60). Llamándola "hourí", estos sujetos musulmanes le prometen a la cristiana un compañero decente y, por ende, una religión a la que puede convertirse para gozar del respeto, amor y compañía que su virginidad y belleza merecen, tanto en el paraíso terrenal -al-Ándalus- como en el celestial - $\hat{Y} \bar{a} n n a-$.

De nuevo es rotunda la negación de la cristiana ante el proselitismo islámico. Ello genera que: 1) el capitán gomel, por su noble generosidad y caballerosidad, se

\footnotetext{
La alteración de esta rima quizá sea una de las arbitrariedades que Zorrilla, debido a lo indisciplinado, desatado y excesivo propio del romanticismo (Cossío, 1946), cometió en sus metros y rimas.

4 Compárense la rima de esta copla en su versión de 1844 (la que se suele reproducir): «Adiós, hourí idolatradal del corazón africano;/ pues que por suerte traidora/ te pierdo agora,/ muere con tu Dios cristiano,/ yo moriré en mi fe mora»; y la de 1905 (la publicada también en la Biblioteca Virtual Miguel de Cervantes): «Adiós, hurí seductora,/ rosa de pensil cristiano;/ pues que por suerte traidora/ te pierdo agora,/ muere con tu Dios cristiano,/ yo moriré en mi fe mora».
} 
resigne y libere a la cautiva (“dijo, como quien medita,/ en la mejilla una lágrima:/ [...] hourí del Edén, no llores, / vete con tus caballeros._-//Y dándola su caballo/ y la mitad de su guardia,/ el capitán de los moros/volvió en silencio la espalda”, Zorrilla, 1943: 48); 2) el caballero cordobés desista de su conquista y se execre (“¡Maldita, hermosa, mi estrella!/ ¿Qué ha de valerme la vida,/ si no he de hallarte con ella/ ni en Granada la florida,/ ni en mi Córdoba la bella?", Zorrilla, 1943: 60); 3) el caballero moro impreque a la amada ("pues que por suerte traidora/ te pierdo agora,/ muere con tu Dios cristiano,/ yo moriré en mi fe mora", Zorrilla, 1943: 449). Las tres respuestas corresponden, respectivamente, a: 1) la resignación, aceptación y respeto por el cristianismo; 2) la reprobación del islam; 3) la maldición del cristianismo. Con las tres, Zorrilla consigue escenas efectistas y llamativas de cara al público tradicional para afirmar, por medio de las figuras patéticas -1) exclamación, 2) execración, 3) imprecación - la supremacía y absolutismo del cristianismo como religión de España.

Esta superioridad de la amada -que es lo mismo: la del cristianismo representado por ella- se afirma simbólicamente mediante las dos partes antitéticas del régimen diurno de lo imaginario (Durand, 1982). En O3, la cristiana y su presencia aparecen vinculadas al "sol" y el día ("aurora", "arrebol") -símbolos espectaculares ${ }^{5}$, y aun a una "luna" eufemizada, por tratarse de un centro luminoso durante la noche ${ }^{6}$. La ausencia de la cristiana y, por consiguiente, el rechazo, angustia, lamento y desesperación del amante - que es lo mismo: la representación del islam-se asocian con la "noche" y las "tinieblas" -símbolos nictomorfos?-:

De hoy me será el claro sol una lámpara importuna; hija del suelo español, tú eres mi sol y mi luna... la aurora y el arrebol.

Pues en ti pierdo el sol hoy, sin tu sol no he de vivir; sultana, a Córdoba voy, que en las tinieblas que estoy presto, a fe, que he de morir. (Zorrilla, 1943: 60)

La cautiva, la dama y la noble cristianas parecen representantes de aquel ejército de luz que satanizó al enemigo y contra el cual la Reconquista -solar y espectacular empresa- constituyó "una acción meritoria, de la que se deriva[ro]n beneficios penitenciales y espirituales tan importantes como el perdón de los pecados, la absolución de las penitencias o, más trascendente aún, la salvación eterna" (García Fitz, 2009: 191-192).

Queda clara, pues, la superioridad de la cautiva, la dama y la noble cristianas -la superioridad del cristianismo-; pero, ¿qué pasa cuando la amada es una musulma-

\footnotetext{
Los símbolos espectaculares se asocian con la luz, lo solar, la videncia y la palabra (Durand, 1982).

6 Los símbolos de la inversión pertenecen al régimen nocturno y buscan eufemizar todos los valores del régimen diurno a través del esquema del descenso (Durand, 1982).

7 Los símbolos nictomorfos se refieren al ámbito de las tinieblas y la oscuridad (Durand, 1982).
} 
na? El anterior esquema simbólico parece invertirse en O5: sultana cordobesa-sol/ mancebo cristiano-noche. Sin embargo, esta mujer y la sultana nazarí de O4 no son simples concubinas de opulentos harenes. Ellas no reproducen este exótico arquetipo romántico de lo erótico, misterioso y atractivo (Litvak, 1985). Ambas, prisioneras de las circunstancias, ambiente y magnificencia del harén, problematizan la libertad de la mujer musulmana.

Aunque en el cristianismo y el islam existen preceptos de dominación sobre la mujer, a Zorrilla parece molestarle el arquetipo de harén -tan reproducido por la literatura y la pintura en el XIX- para el goce y morbo de los hombres occidentales. Zorrilla participa del pensamiento popular contra la idea de placer y relajación moral que se achacaba a los hispano-musulmanes y se extendió equivocadamente a todos los países de habla árabe. Tal generalización es falsa, ya que en al-Ándalus se desarrolló un sincretismo con aportes hispánicos, que diferenció su cultura de la del califato de Damasco. Aun así, Zorrilla acató esta generalización sobre los estados morales musulmanes, apartó la vida de placer y riquezas del harén, y llevó a que estas dos sultanas de $\mathrm{O} 4$ y $\mathrm{O} 5$ objetaran lo propio y desearan lo otro, ya que el interior del harén -que es lo mismo: del palacio musulmán o de al-Ándalus- configura una prisión y, en consecuencia, aquellas ansiaban "la libertad que rezuman los elementos de la naturaleza" (Hatamleh, 1972: 65); o sea, el exterior, el espacio legitimado como natural, libre y que, en efecto, se encontraba afuera: en España. Recuérdese que el discurso de la Reconquista ofrecía un sentido de libertad: la reconquistadora era una empresa decisiva para forjar la vida libre (Sánchez-Albornoz, 2001). No son de extrañar, en este sentido, pues, la sintética respuesta de la nazarí ni el resaltado que Zorrilla hace de las dos últimas palabras de aquella, frente a las preguntas del sultán:

«Tienes torres, dijo el moro,

»perlas y oro

"y guirnaldas en la sien;

»dime, hermosa, a tu ventura

"y hermosura

»lo que falta en el harén.

"¿Qué hay en el huerto sombrío

"y en el río,

"y en el ave y en la flor,

»que al rayar el claro día,

»¡ivida mía!

»no te traiga tu señor?

»Di, ¿qué falta a tu belleza,

»a tu riqueza

»o a tu loca voluntad?»

«Señor, esos ruiseñores

»en las flores

»tienen aire y libertad.» (Zorrilla, 1943: 119)

Por tanto, las sultanas nazarí de $\mathrm{O} 4$ y cordobesa de $\mathrm{O} 5$ no son simples mujeres arquetípicas de harén, sino voceras ideológicas de la Reconquista, quienes, desde su disfraz musulmán, ratifican la supremacía del cristianismo y el espacio español frente al credo, costumbres, moral y espacio de la alteridad. A ellas se otorga un 
papel relevante en un período, cuando la mujer gozaba de poca o ninguna presencia sociopolítica.

Como se colige, es imposible poner a prueba a la amada. En las seis orientales de Zorrilla, la figura femenina, enmascarada de cristiana o musulmana, materializa los valores del cristianismo porque estos, frente a los del islam, son los verdaderos, los avanzados, los de Occidente; los que garantizan el progreso con base en la tradición.

\subsection{El hombre bipartito}

¿Qué sucede con la figura masculina? Se observan al menos tres máscaras.

Primero, en $\mathrm{O} 5$ se viste de mancebo cristiano, enamorado de una sultana cordobesa, quien lo traiciona por no corresponderle y, por ello, esta recibe su imprecación: "Quédate, aunque yo te amaba,/ por esclava/ de un señor y de un harén,/ y muera con tu hermosura/ la ventura/ de tu existencia también" (Zorrilla, 1943: 247). Tal imprecación está motivada, en parte, por el tópico de la lírica árabe (clásica y andalusí) y provenzal (Galmés, 1996), que Zorrilla toma: la albada, la aurora que viene a interrumpir los amores, obliga a la separación y provoca que se maldiga al alba y, como en este caso, también a la amada (recuérdese que ella está asociada con la luz solar): "Larga y pesada es la noche/ para quien tanto aguardó,/ que el alba por el oriente/ viene a ahuyentar su pasión” (Zorrilla, 1943: 246).

Segundo, la figura masculina que habla en O1 resulta ambigua. Al comienzo pareciera ser heraldo de un sultán cordobés. La riqueza material que este le podría dar a la cristiana es tal, que el sujeto lírico lo compara anacrónicamente con Abū 'Abd Allāh Muhammad XII o Boabdil el Chico (1459-1533), el último rey de Granada. Por pactar con los Reyes Católicos la rendición del reino el 25 de noviembre de 1491 y entregarlo a la corona de Castilla el 2 de enero de 1492 (Montgomery Watt, 1974; Peinado y López de Coca, 1987; Álvarez de Morales, 2015), Boabdil pasó a la historia y el pensamiento popular como cobarde o traidor. Al retomar esta figura histórica, el sujeto lírico sugiere analógicamente que las riquezas ofrecidas por el sultán cordobés esconden un engaño, un doble juego: no hay que fiarse de ellas. De ahí que, al final, en una unidad distinta y enfatizada por el blanco interestrófico, el sujeto lírico reitere a modo de estribillo la primera estrofa. Mediante la repetición y el paralelismo, el ofrecimiento material del sultán cordobés queda anulado por el del sujeto lírico: un ofrecimiento exaltado de mil cielos, que gana en favor y, sobre todo, en motivación espiritual (Hatamleh, 1972). Sin embargo, no ofrece lo espiritual islámico, sino lo cristiano. En sus palabras, el sujeto lírico, mediante la hipotaxis condicional del último verso, inscribe sutil e irónicamente el cuestionamiento de la creencia islámica de los siete cielos (Corán 65: 12) y, como contraargumento, asevera implícita la existencia de un único cielo, el cielo cristiano, donde se promete la verdadera vida y la gloria (2 Pedro 3: 13): "te diera de buena gana/ mil cielos, si fueran mil" (Zorrilla, 1943: 37). Como se ve, el lector se enfrenta en O1 a un doble doble juego. No solo encuentra un doble interés de sujeto lírico: ¿habla en nombre del sultán cordobés o de sí mismo?; sino también una indeterminación del hablante: ¿quién es el sujeto lírico? ¿Es musulmán o cristiano? ¿Es acaso un desdoblamiento de Zorrilla? En O1, por ende, el sujeto lírico se vale de la ambigüedad literaria para confundir el lugar cultural de enunciación y enmascarar el discurso cristiano. La construcción formal e ideológica de este sujeto es compleja y no corresponde a un simple piropo castizo en boca de un moro, como apenas vio Carrasco Urgoiti (1956). 
Tercero, la figura masculina se presenta como un protagonista musulmán enamorado de una musulmana en O4; o de una cristiana en O1, O2, O3 y O6. Según Carrasco Urgoiti (1956), O1 y O2 inician la moda de cantar el amor idealizado de un musulmán por una cristiana. No obstante, Hatamleh (1972) advierte que el tema de un musulmán prendado por una cristiana, y viceversa, procede del romancero popular castellano y resurge con mayor fuerza sentimental y exótica durante el romanticismo. Frente a la negación y rechazo de la amada, ya se han expuesto las reacciones abnegada, execrada y desconcertada del capitán gomel, el caballero cordobés y el sultán nazarí en O2, O3 y O4, respectivamente. Sin embargo, Zorrilla logra construir un protagonista musulmán sui géneris en O6. El caballero moro asiste al pie de la ventana del castillo donde la noble cristiana permanece. Desde allí le canta-como despidiéndose-, esperando contemplarla:

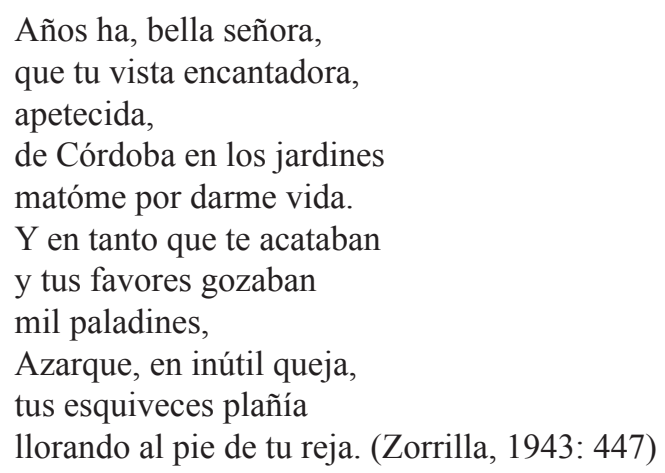

Obsérvese que, mediante la metáfora apositiva, el caballero se compara con Azarque de Granada. Era frecuente que los poetas románticos castellanos retomaran del romancero morisco figuras con existencia real, de quienes quedó el recuerdo de su nombre debido a su gloria o celebridad (Seco de Lucena, 1963). Así actúa Zorrilla cuando retoma la figura de este guerrero de linaje almohade, quien un día se despidió de su amada Adalifa (a veces también se la llama Celindaja), hija de Celin Hamete, porque se embarcaba a la guerra. Él le pidió que lo esperara y ella le respondió que se encerraría a esperarlo. Sin embargo, Azarque terminó con ella, porque no creía en su amor ni celos. Le pidió que lo olvidara. Ella aceptó sus palabras y, en su ausencia, se enamoró de otro. A su regreso, Azarque la acusó de fácil y haberle mentido en su amor. Al final, el guerrero partió de Sevilla hacia el combate, pensando en Adalifa. La maldijo a que sufriera con el otro amante, mientras él se marchó a la jornada, la cual reconoce como causa de la mudanza de los sentimientos de Adalifa. Ella le dijo que aunque se fuera no podría vivir sin él; que podría encontrar a otras moras más espléndidas, hermosas y valientes, pero jamás a una que lo amara como ella (Durán, 1834; Ochoa, 1838). En fin, Azarque le cantó su amor y sufrimiento a Adalifa al pie de su ventana. El escenario y el conflicto sentimental justifican la comparación, al tiempo que este personaje popular le permite a Zorrilla evocar, en apoyo de su discurso, los últimos años de dominación musulmana.

Ante la lamentación del caballero moro, la amada se asoma a la ventana y replica: "«Cristiana, ¡oh moro!, nací,/ y me matan con rigor,/ ¡ay de mí!,/ mi religión y mi amor,/ y huyo a mi pesar de ti./ Huye de aquí»”" (Zorrilla, 1943: 448). Aquel responde defendiendo su amor: “¡Ah!, iqué importa que al Profeta/ en adoración secreta/ yo bendiga,/y 
adores tú al Nazareno,/ si en blanda coyunda amiga/ un solo amor nos uniera!" (Zorrilla, 1943: 447). En eso sale del castillo el conde, hermano de la joven, y amenaza al moro. Este contesta: "- Yo cristiano no soy, repuso el moro;/ yo no soy sino amor para tu hermana;/ ¿mas qué importa mi fe ni la fe suya/ si como yo me ama?” (Zorrilla, 1943: 449).

¿Qué está proponiendo el caballero moro, sino olvidar los credos, desestimar las causas religiosas que vuelven incompatible el amor, para apostar entonces por un amor puro (udrí, ideal, platónico, romántico)? ¿Qué está proponiendo el caballero moro, sino una crítica contra los factores ónticos (territorio, raza, valores culturales) que el discurso decimonónico de la Reconquista canta y difunde; los valores sobre los cuales se pretende edificar la sociedad y el nacionalismo españoles? En la voz del caballero moro, en efecto, se escucharía implícita la voz del Zorrilla liberal que abre espacio para pronunciarse también entre las aparentes orientales tradicionalistas. Es la voz que viene a recordar de qué forma, tanto en la Edad Media como en el siglo XIX, la institución religiosa desvirtuó la historia en función de los intereses políticos, nacionalistas, románticos, míticos y colonialistas.

Sin embargo, esta voz recibe inmediata censura: "-No blasfemes, infiel, si en tu creencia/ tornaras a mirar estas murallas,/ tú lo juraste, moro, que conmigo/ serías en batalla" exclama el conde (Zorrilla, 1943: 449), quien convoca al caballero moro al medieval duelo por honor. Con esta práctica ligada al código social, moral y religioso, el conde busca resarcir la falta cometida por el "infiel" contra la fe cristiana. Pese a la convocatoria, el caballero moro se desarma, se despide de su amada imprecándola ("«Adiós, hourí idolatrada/ del corazón africano;/ pues que por suerte traidora/ te pierdo agora,/ muere con tu Dios cristiano,/ yo moriré en mi fe mora»", Zorrilla, 1943: 449) y se entrega abiertamente a la embestida del conde, es lanzado al avivado río -obsérvese la intensificación del río mediante la prosopografía: "estrepitosas se derrumban/ entre espumas las aguas" (Zorrilla, 1943: 448)- donde muere herido y ahogado.

¿Qué hay detrás de este trágico final -"muy del momento y apetecido por el público romántico" (Hatamleh, 1972: 55)-, sino una burla contra el discurso de la Reconquista, una forma de resistirse a él y desestabilizarlo? El caballero moro encara con sarcasmo a la amada -al cristianismo- $\mathrm{y}$, asumiéndose como un sujeto pleno y subversivo, prefiere suicidarse: negarse a obedecer al sistema hegemónico. Él no renuncia a su vida por la imposibilidad de amar; no recurre al tópico suicidio romántico: la solución dramática ante la decepción y desesperación (Díaz-Plaja, 1967). No, el caballero moro se suicida porque, siendo el otro, no tiene ningún vínculo con la patria, la religión, la raza ni la cultura españolas y, por ende, acepta la muerte para liberarse social y personalmente de la discursividad hegemónica cristiana y sus imposiciones sociopolíticas. Parafraseando a Rojas (2012), podría decirse que el suicidio del caballero moro busca desenmascarar lo siniestro que el discurso nacionalista español ejerce imaginaria y concretamente contra el otro, para instituirse. El suicidio es la única manera que el otro tiene para encontrar alivio frente a la amada, el cristianismo y su opresión.

En síntesis, la figura masculina en las seis orientales de Zorrilla se enmascara en forma de tres amantes (el cristiano, el ambiguo musulmán-cristiano, el musulmán), que al final se resuelven en dos tipos de hombre. Por un lado, el que, dentro del esquema actorial $^{8}$, participa de la afirmación de la figura femenina y,

8 El esquema actorial se refiere a la tensión sujeto-objeto, las relaciones de los actantes, en el texto poético (López-Casanova, 1994). 
por ende, la representación hegemónica del discurso de la Reconquista. Para ello, Zorrilla retoma del código poético de la lírica cortés árabe y provenzal los tópicos de la superioridad de la amada, el rechazo del amado y la albada. Por otra parte, se encuentra el hombre que pone a prueba y subvierte la filosofía, la palabra oficial y la verdad del discurso hegemónico, proponiendo un nuevo paradigma social e imaginario de libertad.

\subsection{Las huellas colonialistas}

Said (1990) denominó "orientalismo" al complejo aparato de ideas eruditas (académicas o artísticas), socioeconómicas, políticas, militares, autoritarias y coloniales institucionalizadas especialmente por Gran Bretaña y Francia respecto de Oriente, desde finales del siglo XVIII hasta la Segunda Guerra Mundial. El orientalismo británico-francés motivó el orientalismo español; sin embargo, este no fue un orientalismo en el sentido estricto del término (Gil Bardají, 2008). En España se dio el arabismo: un orientalismo más genérico y académico. A pesar de esto, los orientalismos europeo (franco-británico) y español comparten la construcción de discursos de alteridad, la experiencia colonial y la influencia ejercida por el romanticismo en los círculos intelectuales del siglo XIX (Morales Lezcano, 1988; López, 2011; Cabo Aseguinolaza, 2012).

El orientalismo español y la consecuente carga colonialista del concepto de Reconquista se inscriben de forma sintética en un solo adjetivo en O6. El conde primero llama "infiel" al caballero moro y después "mahometano". Denominar mahometismo a la religión musulmana es un error teológico. "Islam" es el término correcto para designar a esta religión. El término "mahometano" demuestra la ignorancia y malinterpretación que el cristianismo y Occidente han tenido sobre el islam y el profeta Mahoma. Southern (1962) evidencia cómo en el siglo XII se atribuyó a Mahoma el carácter de los profetas de espíritu libre. En ese momento, surgieron en Europa profetas que reclamaban adeptos. Esta coyuntura llevó a considerar a Mahoma propagador de una revelación falsa y, en consecuencia, se lo convirtió en compendio de lascivia, libertinaje, sodomía y demás perfidias derivadas de sus fraudes doctrinales. En el siglo XIII, se creyó que Mahoma era un apóstata astuto; mientras que en el XIX y XX, representante de una herejía arriana de segundo orden. El caso de Mahoma ejemplifica cómo Oriente adquirió representantes con alguna exigencia occidental: aquel profeta se transformó en pseudoencarnación repetitiva de un gran original como era Cristo, Europa u Occidente. No obstante, para los musulmanes su profeta no tiene carácter divino, pues Mahoma solo es un humano al que Alá escogió por sus virtudes para hacerlo portavoz de Su palabra. El Corán (34: 28) insiste en su incapacidad para hacer milagros, debilidad mortal y su mero papel como transmisor de la voluntad divina. Los musulmanes no adoran a Mahoma como los cristianos a Jesús. Aquel ni siquiera es el único profeta: hay otros y, entre ellos, Jesús.

La occidentalizada homologación entre Mahoma y Jesús se inscribe en O3, cuando el caballero cordobés expresa: "Ha prometido Mahoma/ un paraíso, una hurí..." (Zorrilla, 1943: 60). Mahoma no promete nada como Jesús. Como se dijo, aquel solo transmite el mensaje de Alá, quien es el real Prometedor del paraíso y la vida eterna. El calificativo "mahometano" y la homologación de Mahoma con 
Jesús, por tanto, comprueban una vez más cómo el orientalismo se fundamenta en la exterioridad:

en el hecho de que el orientalista, poeta o erudito, hace hablar a Oriente, lo describe, y ofrece abiertamente sus misterios a Occidente, porque Oriente sólo le preocupa en tanto que causa primera de lo que expone. Lo que dice o escribe, en virtud de que está dicho o escrito, pretende indicar que el orientalista está fuera de Oriente tanto desde un punto de vista existencial como moral. (Said, 1990: 41)

Justamente porque el mahometismo es lo otro, lo de fuera, es necesario limpiar su inmoralidad y herejía. En este sentido, cobra relevancia el río donde cae el caba1lero moro, en aquel final trágico de O6. El agua fluvial figura en ese contexto como símbolo diairético ${ }^{9}$, que purifica y libera de la mancha "infiel", mahometana ${ }^{10}$. En el poema, el río se lleva el cadáver del moro. Y se sabe que la mayoría de ríos desemboca en el mar. La imagen fluvial, por tanto, apela no solo a la limpieza, sino también a la expulsión de los moriscos de la monarquía española entre 1609 y 1614, por orden de Felipe III, desde los diferentes puertos de Valencia, Murcia y Andalucía. Este hecho fortaleció en el nivel político la homogeneización católica en la monarquía y su defensa de la Iglesia en el siglo XVII. Este hecho mitificó la configuración de una españolidad pura, sana y limpia en el siglo XIX. La precipitación del caballero moro en el río, en fin, corresponde a un símbolo catamorfo ${ }^{11}$, ya que representa la caída de la política, sociedad y religión musulmanas en España y Europa.

En definitiva, las dos huellas colonialistas en $\mathrm{O} 3$ y $\mathrm{O} 6$ manifiestan, por un lado, cómo la construcción histórica española indaga en el pasado nacional, su esfuerzo por situarse con respecto a la Europa moderna y su tradición orientalista; y, por otro, cómo el discurso de la Reconquista reproduce la consideración y valoración absolutamente desvirtuadas y erróneas sobre el islam, pero contribuyentes de la rentable idea política y metafórica del otro. Pareciera que Said se refería a estas dos huellas colonialistas cuando afirma: “'Religión mahometana' es la designación europea apropiada (e insultante); 'islam', que precisamente es el nombre musulmán correcto, es relegado a otra entrada. La 'herejía [...] que nosotros llamamos mahometana' está 'tomada' como la imitación de una imitación cristiana de la verdadera religión” (Said, 1990: 93).

\subsection{La raza endiosada}

Hacia 1840, en el ambiente español circulaba el concepto de raza, despojado del exclusivismo biológico y la superioridad evolutiva étnica, por influencia de obras como la del conde Gobineau y la divulgación del darwinismo social (Litvak, 1980; Zuleta, 2000; Álvarez, 2002). Dicho concepto se comenzó a perfilar como mito o elemento

9 Los símbolos diairéticos se refieren al héroe, la virilidad, las armas, la belicosidad y la purificación (Durand, 1982).

10 Son ilustrativas de esta limpieza en el plano histórico las palabras de García Fitz (2009: 191): "Su presencia en ciudades y tierras que habían pertenecido a la Cristiandad no sólo tenía que ser erradicada mediante conquista, sino que además sus huellas debían ser purificadas, limpiadas y destruidas, porque su estancia dejaba un poso de inmundicia y suciedad, una contaminación "Mahomética" que resultaba intolerable precisamente porque representaba una polución claramente demoníaca: como afirma el autor de la Chronica Adefonsi Imperatoris en relación con la toma de Coria por las fuerzas de Alfonso VII, «postquam autem reddita est ciuitas imperatori, mundata est ab immunditia barbarica gentis et a contaminatione Mahometis et, destructa omni spurcitia paganorum ciuitatis illius et templi sui...»"

11 Los símbolos catamorfos remiten a la caída, el abismo y la carne (Durand, 1982). 
esencial para una comunidad lingüística, religiosa o nacional de los pueblos hispánicos contra el estilo de vida y cultura de los Estados Unidos (Van Aken, 1959; Litvak, 1980). Raza, pues, equivalía a cultura, y se empleaba como símbolo de los lazos tradicionales que ligaban a España con su pasado imperial y aun con Hispanoamérica.

En sus orientales, Zorrilla perfila a la raza española, oponiendo los calificativos cristiano $\{-\mathrm{a}\}$ y nazarena a gentilicios como árabe, moro (natural de África septentrional frontera a España), africano, gomel ${ }^{12}$ (bereberes de la Gomara, región histórica y cultural coincidente con la actual Yebala, Marruecos, al este del estrecho de Gibraltar), granadino y cordobés. Para Zorrilla, por tanto, hablar de raza española implica metonímicamente hablar de religión católica. De este modo, ni los conversos al islam ("Si ya no eres cristiano, tu rodela/ y ese corcel apresta que descansa", Zorrilla, 1943: 448), muladíes, mozárabes, ni los mudéjares eran de raza española. Como se manifiesta en el contexto sociocultural, nada tienen que ver lo biológico ni las etnias y ello se observa en O5, cuando metonímicamente se describe a la sultana cordobesa: "blanca mano/ que tal vez le hace traición" (Zorrilla, 1943: 246). Pesa más el hecho de ser musulmana, antes que blanca, para no ser considerada de raza española.

Del conjunto léxico sobresalen los términos "moro" y "nazareno". Si bien el primero se refiere, imprecisamente, a cualquier musulmán que habitó en España desde el siglo VIII hasta el XV (RAE, 2014), este es un término popular y coloquial, con connotaciones peyorativas o no, de acuerdo con el emisor o receptor; en todo caso, desde la Edad Media hasta ahora posee una carga racista, discriminatoria y xenófoba (Pérez-Reverte, 2014), la cual se escucha claramente en las seis orientales. Aparte de indicar a un natural de Nazaret, "nazareno" constituye el determinante de "cristiano" en la lengua árabe y de esta ha quedado dicha acepción en español, en sentido figurado (Hatamleh, 1972). Es llamativo el uso generalizado de un determinante árabe para definir a la raza española. Con epítetos como "sultana", "hourí" o "nazarena" y nombres como "harén", Zorrilla introdujo una renovación léxica asociada a lo árabe en la poesía romántica española, a pesar de que ciertos precedentes hubieran aparecido en varias composiciones tituladas oriental y publicadas en la revista madrileña El Artista (Carrasco Urgoiti, 1956; Hatamleh, 1972). Zorrilla, pues, proporcionó influyentes términos estéticos e ideológicos a la poesía y el imaginario nacionales.

Por último, obsérvese que la supremacía de la raza española se refuerza en $\mathrm{O} 3$ a través del binomio vencidos/vencedores: "Cuando vuelvan los cristianos/ de los moros vencedores,/ lee mis destinos tiranos,/ la historia de mis amores/ en la sangre de sus manos" (Zorrilla, 1943: 60). Siempre el lugar identitario hegemónico, privilegiado y central se (de)marca mediante binomios. Estos funcionan por una serie de pares opuestos que, sin entrecruzarse, crean estereotipos; por ejemplo: "moro"/"cristiano". Por eso, los binomios garantizan, dentro de la hegemonía, la lógica de la pureza. No es extraño, entonces, que por su exaltación de la endiosada raza española Zorrilla fuera llamado, en períodos nacionalistas como la década de los 20 y previo al franquismo, el más genuino poeta de la raza hispánica (Argüello, 1920; Ibáñez, 1920; Rodríguez Marín, 1934; Ramírez, 1935).

\subsection{Los límites en retroceso}

Dentro de la hegemonía, los binomios garantizan asimismo la dinámica dentro/fuera. Por eso, el trazado de la patria es simultáneo a la definición de raza.

12 Los gomeles constituían un cuerpo de élite del reino nazarí de Granada (Díez y Díez, 2005). 
La delimitación imaginaria y concreta del territorio español se sintetiza en el verso paradigmático de O3: "hija del suelo español" (Zorrilla, 1943: 60). Pero, ¿dónde está ese "suelo español", ese lugar no marcado de la hegemonía que se asume como neutro y universal? Se dan dos coordenadas. En O2 se alude, a través de los castillos y torres, a León; y en O6, a través del conde, a Castilla. El proceso de la Reconquista moldeó más a unos reinos cristianos que a otros. Desde mediados del siglo IX, la monarquía asturleonesa se encomendó a la defensa y restauración del cristianismo frente al islam, así como a la recuperación de los dominios visigodos y unidad política de estos. Durante el siglo XI, el reino de Castilla comenzó su guerra contra los musulmanes. En 1230, Castilla y León quedan unificados en manos de Fernando III el Santo y, desde entonces, la dinámica reconquistadora influyó especialmente en la organización constitucional, feudal y económica del nuevo reino; así como en su agresión militar directa y sistemática contra el espacio político andalusí (Mínguez, 1994; Martín, 1996; García Fitz, 2009). Las dos coordenadas, por tanto, corresponden a centros, primero, históricamente estratégicos para trazar el retroceso de los límites del sur y forjar el territorio de la patria; y, segundo, fundacionalmente míticos para resumir en Castilla la esencia básica de España, y viceversa.

Si Castilla y León es el centro, el aquí, la frontera, por ende, el otro está en Córdoba, Granada, Sevilla y sus "mares de oriente"; allí, fuera, donde:

tengo jardines y flores,

tengo una fuente dorada

con más de cien surtidores.

$[\ldots]$

Allí la altiva palmera

y el encendido granado,

junto a la frondosa higuera

cubren el valle y collado.

Allí el robusto nogal, allí el nópalo amarillo, allí el sombrío moral crecen al pie del castillo.

Y olmos tengo en mi alameda que hasta el cielo se levantan, $\mathrm{y}$ en redes de plata y seda tengo pájaros que cantan.

\section{$[\ldots]$}

$\mathrm{Y}$ al rumor del dulce trino peregrino de arpa, bella, y ruiseñor, oído prestan atento agua, viento, olmo, alcázar, campo y flor. 


\section{$[\ldots]$}

«Danme el ánima de un moro, "perlas y oro,

"y coronas en la sien;

»dime, flor, a mi ventura

"y hermosura

»lo que falta en el harén!

»Danme chales los califas

$» y$ alcatifas,

"y guirnaldas en la sien;

»dime, huerto, a mi ventura

»y hermosura

»lo que falta en el harén!

»Danme baños y festines

»y jardines

»que me mienten el Edén;

»dime, río, a mi ventura

"y hermosura

»lo que falta en el harén!

»Transparentes como espumas

»danme plumas,

"y atan velos a mi sien;

»ruiseñor, di a mi ventura

»y hermosura

»lo que falta en el harén!

»Nada al fin que les dé enojos

»ven mis ojos,

»nada que arrugue mi sien;

»dime, luna, a mi ventura

»y hermosura

»lo que falta en el harén!» (Zorrilla, 1943: 47-48 y 118-119)

El otro está donde están las riquezas. Zorrilla sitúa al otro en un al-Ándalus abundante en riquezas naturales y materiales. Construye las topografías de la patria andalusí con base en una amplia serie de elementos exóticos, sensuales, sensoriales y seductores, que sintetiza el primor y delicadeza de sus jardines y alcázares. En contraste, apenas si se refiere a la naturaleza de León: "—Si tus castillos mejores/ que nuestros jardines son,/ y son más bellas tus flores,/ por ser tuyas, en León” (Zorrilla, 1943: 48). Zorrilla, por tanto, opone a la prolífica tierra de al-Ándalus la árida tierra de Castilla; opone al discurso de la ostentación y placer exóticos de las tierras andalusíes el discurso determinista de la tierra y clima castellanos sobre el ser y personalidad de los españoles. Por eso, aquella cautiva, dama y noble cristianas, auténticas castellanas -auténticas españolas-, no dudaron en oponer a los opulentos ofrecimientos materiales e ideológicos del otro la austeridad y sobriedad del cristianismo. Zorrilla de nuevo se vale de la descripción pintoresca para plantear el rechazo de todo aquello que proceda del engañoso paraíso extranjero, que ofrece un vergel celestial $(\hat{Y} \bar{a} n n a)$ y terrenal (al-Ándalus) contrarios a los prometidos por el cristianismo y el "suelo español". 
En definitiva, aunque árido y menos fecundo, el "suelo español" es la tierra castellana: el legítimo centro imaginado de la libertad ("«Señor, esos ruiseñores/ »en las flores/ »tienen aire y libertad»", Zorrilla, 1943: 119), frente a la bárbara periferia del artificio y el cautiverio ("Y en la vega del Genil/ tengo parda fortaleza;/ que será reina entre mil/ cuando encierre tu belleza", Zorrilla, 1943: 47).

\subsection{La insistencia en el padre}

La afirmación de la patria reclama el testimonio de su soberanía. Por eso, la cautiva en $\mathrm{O} 2$ interroga retóricamente al capitán gomel y le suplica la deje regresar a su patria: “—¿Qué me valen tus riquezas,/ respondióle la cristiana,/ si me quitas a mi padre,/ mis amigos y mis damas?/ Vuélveme, vuélveme, moro,/ a mi padre y a mi patria,/ que mis torres de León/ valen más que tu Granada-" (Zorrilla, 1943: 48). La figura paterna aparece en estos versos como símbolo ascensional ${ }^{13}$ al representar el poder militar, jurídico, político, religioso y cultural del reino de Castilla y León y, por consiguiente, de España, frente al poder del califato cordobés o las taifas (califa, sultán, capitán).

En función de esta afirmación de la soberanía española, parece evocarse a tres figuras históricas. Las tres son posibilidades, ya que para Zorrilla, como para el resto de románticos, "la historia no es sino un pretexto poético, encaminado a realzar la exuberancia de los poemas" (Hatamleh, 1972: 42). Zorrilla, en su libertad formal y romántica, juega con la historia, lugares y personajes, sin importarle los anacronismos y errores históricos, los cuales siempre se subordinan a la valoración de las circunstancias.

Por el contexto, la figura paterna en $\mathrm{O} 2$ aludiría al rey Alfonso VII de León (1105-1157), quien avanzó notablemente la Reconquista y llegó a coronarse Emperador de toda Hispania. Desde 1138, este rey intervino en los enfrentamientos entre almorávides y almohades; realizó expediciones, ataques y saqueos para incitar a los andalusíes a sublevarse contra ambas dinastías bereberes. A pesar de esto, ninguna de sus cinco hijas fue raptada por los musulmanes, de modo que la cautiva del poema no apuntaría a ninguna de ellas.

En la edición de 1905, O6 presenta otros dos cambios además del expuesto en el primer epígrafe; como aquel, estos cambios tampoco fueron vistos por la crítica hasta ahora. En la tercera parte del poema, se lee "el Conde de Tendilla llega en tanto" (Zorrilla, 1905: 208) en lugar de "el señor del castillo llega en tanto" (Zorrilla, 1943: 448); y en la cuarta parte, "Marchó el Conde de Tendilla" (Zorrilla, 1905: 208) en vez de "Dijo el noble de Castilla" (Zorrilla, 1943: 449). El cambio evocaría, y no arbitrariamente, a don Íñigo López de Mendoza y Figueroa (1419-1479), segundo hijo del Marqués de Santillana. En 1465, el rey Enrique IV de Castilla creó exclusivamente el título nobiliario del condado de Tendilla para Íñigo, adelantado mayor y capitán general de Andalucía y la frontera de Granada. Por la cercanía con la zona aludida en O6 (Córdoba), la hermana sugerida en el poema podría ser María de Mendoza, esposa de Per Afán de Ribera (1420-1454), tercer adelantado mayor y notario mayor de Andalucía, para quien Isabel la Católica creó en 1476 el título de primer conde de los Morales (Sevilla).

13 Durand (1982) se refiere a los símbolos ascensionales como aquellos relacionados con la posición erguida, la sublimidad, la verticalidad espiritual, la ascensión y la soberanía (militar, jurídica, religiosa). 
La figura del "conde de Tendilla" aludiría asimismo al hijo de López de Mendoza y Figueroa: a don Íñigo López de Mendoza y Quiñones (1440-1515), primer marqués de Mondéjar y segundo conde de Tendilla. Es conocido como el Gran Tendilla, puesto que en 1492 fue designado Alcalde de la Alhambra y Capitán General de la ciudad de Granada; y en 1502, Capitán General del reino de Granada. A partir de tales investiduras, los Mendoza controlaron dos órganos de poder que permanecieron durante casi 40 años unidos al linaje familiar, bajo la prerrogativa militar y jurisdiccional frente a la institución real. El cargo de alcaide propietario de la fortaleza de la Alhambra permitía, desde el centro del antiguo reino nazarí, el control estratégico y simbólico del personal administrativo, castrense y los efectivos militares. La Capitanía General del reino facultaba controlar la última frontera frente al islam y la población mudéjar que difícilmente asimilaba la administración católica. Servía de barrera defensiva e instrumento represor contra la población autóctona. Como máxima autoridad militar del reino, Íñigo mandaba el dispositivo militar, sus componentes y mecanismos de control habilitados para su funcionamiento. Logró articular el patronazgo y las redes de poder en el Antiguo Régimen. Por lo anterior, el segundo conde de Tendilla fue una figura fundadora (Jiménez Estrella, 2005) y un símbolo del poder de la alta nobleza castellana (Hernández Castelló, 2013).

Ya sea por el primer o segundo conde de Tendilla, su figura evoca en el imaginario colectivo del siglo XIX al poderoso linaje de los Mendoza: una familia nobiliaria que, en una coyuntura histórica convulsa como los años siguientes a la conquista del reino nazarí, fue decisiva para recuperar y contextualizar el orden político y militar imperiales.

En relación con este linaje, aparece una tercera figura histórica en los siguientes versos de O1: "Diera la lanza mejor/ del Zenete más bizarro" (Zorrilla, 1943: 36). "Zenete" en el DRAE (2014) dirige a "cenete": 'de la tribu berberisca de Zeneta, una de las más antiguas y principales de África septentrional'. Fuente Ballesteros (Zorrilla, 1993a) da esta aclaración en nota al pie de página, después de escribir "zenete" con minúscula en el poema. En el resto de ediciones, esta palabra se escribe con mayúscula, como lo decidió Zorrilla. Si bien el contexto permite leer la anterior acepción, la mayúscula evoca al marquesado de Zenete (Granada), título nobiliario que Isabel la Católica concedió en 1491 a don Rodrigo Díaz de Vivar y Mendoza (1466-1523), primer conde del Cid y primer barón de Alasquer, primogénito del cardenal Pedro González de Mendoza (1428-1495), quien es hermano del primer Conde de Tendilla. El marqués de Zenete participó en la Guerra de Granada (1482-1492). Obsérvese la emulación que el marqués hace del Cid en su apellido. ¿Qué mayor acto para evocar -casi encarnar- al héroe de Castilla por excelencia y, por consiguiente, exaltar el discurso de la Reconquista? El interés simbólico de Zorrilla por la figura de este marqués parece deberse no solo a su participación en la Reconquista y la evocación que hace del héroe castellano, sino también porque el parentesco entre el marquesado de Zenete y el condado de Tendilla remite al enriquecimiento cultural y artístico que España debe a los Mendoza, según explica Hidalgo Ogáyar:

A partir de los hijos que tuvo el Marqués de Santillana fueron surgiendo distintas ramas nobiliarias en la familia de los Mendoza (Infantado, Tendilla-Mondéjar, Coruña, Zenete, Mélito), a las que se sumaron otros títulos fruto de los matrimonios habidos con mujeres mendocinas (Medinaceli, Haro, Ribera después Duques de Tarifa); muchos de sus miembros, según se sabe, fueron importantes promotores de numerosas obras a lo largo de los siglos XVI y XVII, contribuyendo, de esta 
manera, al enriquecimiento del patrimonio cultural y artístico de la Península Ibérica. (Hidalgo Ogáyar, 2008: §6)

En definitiva, Zorrilla parece enmascarar tras la figura del padre a Alfonso VII de León, Íñigo López de Mendoza y Figueroa, Íñigo López de Mendoza y Quiñones, y Rodrigo Díaz de Vivar y Mendoza. Mitificaría a estas figuras históricas como héroes románticos, símbolos de la Reconquista y la soberanía militar, jurídica, política, religiosa y cultural de la patria española.

\subsection{Un asunto de lenguas}

En O1, el sujeto lírico describe sensual y sensorialmente la boca de la nazarena: "Tus labios son un rubí/ partido por gala en dos.../ Le arrancaron para ti/ de la corona de un Dios./ De tus labios, la sonrisa,/ la paz, de tu lengua mana.../ leve, aérea como brisa/ de purpurina mañana" (Zorrilla, 1943: 37). En la etopeya conseguida en el segundo serventesio, el verso "la paz, de tu lengua mana..." deja oír la valoración de la lengua castellana como transmisora de "paz" y libertad, en medio del restablecimiento político, religioso y cultural del orden español. De nuevo, se escucha en boca del ambiguo sujeto lírico de $\mathrm{O} 1$ una estimación a favor de la hegemonía cristiana.

Se infiere, pues, un rechazo del árabe no por ser la lengua del otro, sino por lo que ella supuso además de la islamización: la arabización que desde el siglo IX permitió la adopción oficial del árabe en la literatura y las ciencias, antes que el persa, el sánscrito, el griego, el romance mozárabe y el latín (Vernet, 1999). Dicha arabización se dio gracias a los nombres, las genealogías, el rito jurídico $m \bar{a} l i k \bar{k}$, la popularidad de la lengua árabe y la comunicación con Oriente Medio (Montgomery Watt, 1974). Mediante la lengua árabe se beneficiaron los progresos culturales andalusíes, que el discurso de la Reconquista rechazaría.

La pintoresca descripción de la boca de la amada sirve de marco a la valoración de la lengua castellana. Al tiempo que se alude directamente a la hermosura de la boca de la nazarena, se exalta indirectamente la belleza, honor y grandeza de la lengua que en 1492 alcanzó unificar a España e institucionalizar sus normas en la primera Gramática castellana, de Antonio de Nebrija. El sujeto lírico de O1 canta, en fin, simultáneamente la boca de la amada y el advenimiento de su lengua. Este asunto de lenguas, este doble juego permite visualizar que, como la amada cristiana, "Siempre la lengua fue compañera del imperio" (Nebrija, 1492: §2).

\subsection{Otras máscaras culturales}

Además de la lógica de la pureza y la dinámica dentro/fuera, los binomios de la identidad hegemónica garantizan el lugar del conocimiento, la civilización y la cultura. Por eso, es posible leer en las orientales de Zorrilla cuatro marcas culturales que enmascaran el discurso de la Reconquista.

\subsubsection{Las fiestas de los toros}

Se evocan las fiestas de los toros contrapuestas a las zambras moras en O1: "Diera las fiestas de toros, / y si fueran en sus manos,/ con las zambras de los moros/ el valor de los cristianos" (Zorrilla, 1943: 37). 
Por un lado, las fiestas de toros es el espectáculo de masas más antiguo de España. Su origen procede de los juegos y sacrificios minoicos. Modificada por los mitos latinos, su costumbre pasa a la península ibérica, se extiende e instaura en ella durante la romanización. Existen registros sobre fiestas de toros realizadas en Cuéllar (Segovia) en 1215; así como de la prohibición de Alfonso X sobre estas prácticas en tanto juegos por dinero. Igualmente, en el reino nazarí se documentan fiestas de fieras, en que probablemente participaron toros. En el siglo XVI, las fiestas de toros se incorporaron en los homenajes a Felipe II en Barcelona. Aunque Felipe V prohibió en el siglo XVIII el toreo a caballo, se innovó en la práctica de las corridas de toros con un sentido similar al actual. En este siglo, se generan dos corrientes regionales de toreo a pie: la vasconavarra y luego la sevillana. En el siglo XIX, debido a la Guerra de Independencia, las fiestas de toros decaen, pero en la década de los 30 resurgen con la figura del torero gaditano Paquiro (18051851). Según Alonso Cortés (1943), Zorrilla tomó el motivo de estas celebraciones del poema "Fiesta de toros en Madrid", de Nicolás Fernández de Moratín.

Por otra parte, las zambras evolucionaron de las danzas musulmanas y fueron las fiestas que efectuaban los moriscos con bulla, regocijo y bailes (RAE, 2014). De ellas derivaron las danzas flamencas de los gitanos de Granada y Almería.

Como se colige, la confrontación de ambos festejos de masas busca oponer a la herencia y entretenimiento trivial de los moros el valor y la carga mítica grecolatina de la fiesta de los cristianos y, por ello, representativa de la españolidad. Es significativo observar que durante los siglos XIX y XX las fiestas de toros recogieron el sentido mítico y cultural de la tradición grecolatina por intervención románica, justamente en un período, cuando la historiografía defendía igualmente que España no había nacido en el siglo XII como demuestra Castro (1966), sino con los romanos. En la literatura y la historia románticas, pues, se dieron anacronismos y lecturas interesadas, a fin de consolidar la identidad nacional española. De ahí que las fiestas de toros aparezcan en $\mathrm{O} 1$ y el discurso de la Reconquista como máscara del nacionalismo.

\subsubsection{La prueba del vestido}

Además de llamarla "sultana", "hourí" y ofrecerle riquezas materiales y espirituales, se invita a la cristiana a un cambio de vestimenta en $\mathrm{O} 1, \mathrm{O} 2$ y O4. Frente al parco "morado monjil", se trata de seducirla con exóticas, sensuales y coloridas telas y prendas que engrandecerían su hermosura:

¡Oh qué hermosa nazarena

para un harén oriental,

suelta la negra melena

sobre el cuello de cristal,

en lecho de terciopelo,

entre una nube de aroma,

y envuelta en el blanco velo

de las hijas de Mahoma!

\section{$[\ldots]$}

Yo te daré terciopelos

y perfumes orientales, 
de Grecia te traeré velos,

y de Cachemira chales.

$[\ldots]$

»Transparentes como espumas

»danme plumas,

»y atan velos a mi sien (Zorrilla, 1943: 37, 48 y 118)

Obsérvese que la prenda ofrecida es básicamente el "velo". Este es el elemento por excelencia del código de vestimenta islámica impuesto religiosa (Corán 24: 31, 33: 58-9), jurídica y culturalmente a las mujeres. Existen varias prendas tradicionales que van desde la menos hasta la más restrictiva: shayla, hiyab, al-amira, khimar, chador, niqab y burka. Con ellas se debe cubrir, en diferentes grados y según la región geográfica, la cabeza, cara, senos, cuerpo y genitales, con excepción de manos y pies. El "velo" simboliza la modestia de las mujeres ante varones adultos que no son familiares inmediatos, la reclusión o la privacidad de la esposa en el ámbito público.

El ofrecimiento del "velo" a la cristiana implica, como se ha señalado arriba, el deseo de conversión religiosa, jurídica y cultural al islam, el vestirse, asumirse, seren el sentido etimológico de la palabra- auténtica musulmana ${ }^{14}$; y, por ende, el verse reducida según Zorrilla - la voz del cristianismo-al ostentoso, inmoral y aprisionante harén. Paradójicamente, ante el romántico arquetipo de la exótica y sensual mujer de Oriente, este "velo" zorrillesco retoma toda la implicación de esta prenda en el islam para evocar y, por consiguiente, cuestionar el cubrimiento religioso, sociológico e ideológico que el otro ha tenido o puede volver a tener sobre "la del morado monjil" -el cristianismo- en España y Occidente.

Por lo analizado, obsérvese que el "velo" y el "harén" corresponden, en el plano imaginario de las orientales de Zorrilla, a símbolos nictomorfos, pues materializarían el arquetipo del lazo: las ataduras que pretenden ligar a la cristiana a la vida y cultos paganos del islam. En este sentido, cobra relevancia el verbo usado paradigmáticamente por la noble cristiana en el verso: "y atan velos a mi sien" (Zorrilla, 1943: 118).

\subsubsection{La arquitectura cristiana}

La "gótica ventana" aparece tres veces en un lugar significativamente evocador como lo es el estribillo en la primera parte de O6: "Escucha, hermosa cristiana,/ mis amores,/ no se estrellen mis dolores/ en los vidrios de colores/ de tu gótica ventana" (Zorrilla, 1943: 447-448).

En su afán por representar la melancolía por el pasado y mezclar lo fantástico con lo real, el romanticismo reivindica el estilo gótico, tanto en el arte como en la literatura, a través de la figura de la catedral. La arquitectura gótica materializó artísticamente la cristiandad latina de Europa Occidental entre los siglos XII y XV. Por eso, el estilo gótico se desarrolló fuertemente en las arquitecturas religiosa (monasterios, iglesias, catedrales), civil (palacios, lonjas comerciales, ayuntamientos, universidades, hospitales, viviendas de la nobleza) y militar (castillos, murallas urbanas). La arquitectura gótica fue el símbolo de la soberanía del cristianismo en el espacio.

14 "Musulmán” deriva de muslim, participio presente de la raíz slm, que significa 'quien se somete a Alá'. 
Por tanto, la "gótica ventana" constituye una metonimia de la arquitectura medieval cristiana. Su reiterada evocación -o más bien, su solemne invocación mediante el estribillo- enmascara un canto a la representación material y ocupación espacial del cristianismo en el antiguo régimen español. Por eso, el caballero moro que será vencido -o estallado, según el verbo que en el estribillo aparece como prolepsis del trágico final- se arrodilla, se doblega y entona su serenata al pie justamente de la "gótica ventana", detrás de la cual está mirando, desde arriba, la noble cristiana - el cristianismo-.

\subsubsection{Las artes y ciencias de Occidente}

Por el rechazo de la noble cristiana, al caballero moro en O6: "La voz se heló en su garganta,/ cayó y rompióse la lira; al moro estática mira,/ mas ya ni le ve ni canta" (Zorrilla, 1943: 448). ¿Por qué el caballero usaba una "lira" y no un instrumento de cuerda andalusí como el laúd, el rabel, la mandora o la guitarra morisca? Estos desde el siglo XIII se emplearon para la música y poesía cortesanas, bailes y canciones populares (López, 1983).

Mitológicamente, la "lira" fue inventada por Hermes o la musa Polimnia; es el instrumento de Orfeo; simboliza a los poetas, la armonía cósmica; y, en la iconografía cristiana, evoca la participación activa de la unión beatífica (Chevalier y Gheerbrant, 1988).

Más que evocar el sustrato cultural helénico sobre el cual los árabes también lograron construir sus conocimientos, artes y ciencias, la "lira" aparece, en manos del cantor-poeta moro de Zorrilla, como sinécdoque del pensamiento mitológico, artístico, cognitivo e iconográfico con que Occidente se ha construido y representado armónica, civilizada y clásicamente a sí mismo frente a la alteridad caótica y bárbara, a pesar de sus saberes milenarios que de nuevo parecen no importar.

\section{La voz enmascarada de la Reconquista}

En conclusión, las seis orientales de Zorrilla participan mayormente de una conciencia cívica conservadora; manifiestan los incipientes ecos del discurso nacionalista, romántico y colonialista de la Reconquista; y contribuyen con la representación imaginaria y colectiva de la identidad nacional española, dentro del dividido panorama sociopolítico de primera mitad del siglo XIX.

Zorrilla, en cuanto estratega textual, toma del romanticismo la idealización de la mujer amada, la sensorialidad y sensualidad, y el exotismo para enmascarar (in) conscientemente un sentido patriótico fundado en:

1) El medievalismo romántico que, como afirma Díaz-Plaja (1967), va siempre unido a la valoración del mundo cristiano que, en consecuencia, lleva a una defensa de la moral, civilización y religión cristianas frente a los excesos revolucionarios del liberalismo y del islam, su cultura y costumbres.

2) El colonialismo español que contribuyó con la fabricación histórica y política del otro.

3) El concepto de raza que sirvió para identificar a la comunidad cristiana.

4) La delimitación de sociedades de frontera: el centro, patrimonio, libertad y el yo castellano-españoles frente a la periferia, materialismo, cautiverio y otre- 
dad moros; ecuación que particularizó en España la territorialidad e identidad occidentales frente al lugar marcado de la alteridad oriental.

5) La afirmación y evocación de la soberanía imperial española.

6) La supremacía de la lengua castellana, su comunidad lingüística y cultural.

7) La antítesis propia del régimen diurno de lo imaginario, la cual permite representar, respectivamente, al cristianismo, la pureza de su raza y la soberanía española con símbolos espectaculares, diairéticos y ascensionales; en oposición al islam, la vida musulmana y su caída sociopolítica en Occidente, representados con símbolos nictomorfos y catamorfos.

8) El uso simbólico e ideológico de figuras arquetípicas (el califa cordobés, el sultán y sultana de las taifas andalusíes, el harén, la dama cristiana medieval, el caballero moro o cristiano, el noble castellano, el capitán musulmán), históricas mencionadas (Boabdil) o posiblemente aludidas (Alfonso VII de León, Íñigo López de Mendoza y Figueroa, María de Mendoza, Íñigo López de Mendoza y Quiñones, Rodrigo Díaz de Vivar y Mendoza), propias del romancero morisco (Azarque de Granada), míticas (huríes) y estereotípicas (infiel/fiel, mahometano/nazareno, vencido/vencedor).

9) La ambigüedad literaria en favor de la afirmación del discurso de la Reconquista.

10) La recurrencia de figuras descriptivas (enumeración, prosopografía, etopeya, topografía), patéticas (exclamación, execración, imprecación, apóstrofe, interrogación retórica, súplica) y tropos (metáfora, metonimia, sinécdoque), con el propósito de reforzar estilísticamente el discurso reconquistador.

11) Los tópicos de la superioridad de la amada, el rechazo del amado y la albada, tomados de la lírica cortés árabe (clásica y andalusí) y provenzal.

Aun así, la voz liberal de Zorrilla encuentra espacio y desde O6 propone una concepción de amor romántico, desligado de los factores ónticos defendidos por el discurso de la Reconquista; critica la desvirtuación de la historia en función de la política nacionalista; y subvierte el sistema hegemónico, su oficialidad y represión.

Al final, las seis orientales de Zorrilla no son un simple corpus lírico de tema amoroso como ha señalado la crítica. Sus complejidades formales e ideológicas demuestran, una vez más, que los amores y la literatura no son tan inocentes como parecen.

\section{Obras citadas}

Alborg, Juan Luis, Historia de la literatura española. El romanticismo, Madrid, Gredos, 1980.

Alonso Cortés, Narciso, Zorrilla, su vida y sus obras, Valladolid, Santarén, 1943.

Álvarez de Morales, Camilo, Granada en la Historia de al-Ándalus, Granada, CSIC, 2015. Álvarez, José, "La conformación de una identidad", en Historia de España Menéndez Pidal.

La época de la Restauración (1875-1902), 36 (2), Madrid, Espasa-Calpe, 2002, pp. 5-45. Argüello, Alberto, "Zorrilla, su vida y sus obras", Boletín de la Biblioteca Menéndez Pelayo, 2 (1920), pp. 51-54.

Barja, César, Libros y autores modernos, New York, Selling Agents, 1924.

Blecua, José Manuel, Poesía romántica, I, Zaragoza, Ebro, 1951. 
Cabo Aseguinolaza, Fernando, "El oriente en casa", en Historia de la literatura española. El lugar de la literatura española, Barcelona, Crítica, 2012, pp. 249-332.

Carrasco Urgoiti, María Soledad, "José Zorrilla", en El moro de Granada en la literatura (del siglo XV al XX), Madrid, Revista de Occidente, 1956, pp. 345-388.

Celma, María Pilar, La pluma ante el espejo, Salamanca, Universidad, 1989.

Chevalier, Jean y Alain Gheerbrant, Diccionario de los símbolos, Barcelona, Herder, 1988.

Cossío, José María de, "Prólogo", en Antología de poesías líricas, Buenos Aires-México, Espasa-Calpe, 1946, pp. 9-13.

Díaz Larios, Luis, Antología de la poesía romántica, Tarragona, Unieurop, 1977.

Díaz-Plaja, Guillermo, Introducción al estudio del romanticismo español, Madrid, EspasaCalpe, 1967.

Díez, Miguel y Paz Díez, Antología comentada de la poesía lírica española, Madrid, Cátedra, 2005.

Dobrian, Walter, Poesía española: Neoclasicismo y romanticismo, Madrid, Gredos, 1988.

Durán, Agustín, Romancero general o colección de romances castellanos anteriores al siglo XVIII, Madrid: M. Rivadeneya, 1834.

Durand, Gilbert, Las estructuras antropológicas de lo imaginario, Madrid, Taurus, 1982.

Eguía Ruiz, Constancio, "Un poeta patriótico, don José Zorrilla. Al correr de un centenario", Razón y Fe, 49 (1917), pp. 61-79 y 320-338.

Fuentes Ballesteros, Ricardo de la, "Introducción”, en Antología poética, Madrid, EspasaCalpe, 1993, pp. 9-52.

Galmés, Álvaro, El amor cortés en la lírica árabe y en la lírica provenzal, Madrid, Cátedra, 1996.

García de Cortázar, José Ángel, “La Reconquista en el siglo XI: ¿Geográfica o cultural?”, en IX Centenario da dedicação da Sé de Braga. Congreso Internacional, I, Braga, s.n., 1990, pp. 689-715.

García Fitz, Francisco, "La Reconquista: un estado de la cuestión”, Clío \& Crimen, 6 (2009), pp. 142-215.

Gil Bardají, Anna, Traducir al-Andalus: El discurso del otro en el arabismo español (de Conde a García Gómez), tesis doctoral, Barcelona, UAB, 2008.

Hatamleh, Mohammed, El tema oriental en los poetas románticos españoles del siglo XIX, Granada, Anel, 1972.

Hernández Castelló, María Cristiana, Don Íñigo López de Mendoza, II conde de Tendilla y las artes: ¿Entre España e Italia?, tesis doctoral, Valladolid, Universidad, 2013.

Hidalgo Ogáyar, Juana, "La familia Mendoza, ejemplo de patronazgo femenino en la edad moderna", Nuevo Mundo Mundos Nuevos, 2008. [https://nuevomundo.revues. org/30593\#bodyftn1]. Consulta: 23/02/2015.

Ibáñez, Diosdado, “Zorrilla, poeta lírico", La Ciudad de Dios, 123 (1920), pp. 122-145 y 169-186.

Jiménez Estrella, Antonio, "El conde de Tendilla y su estirpe: el poder político y militar de una familia nobiliaria", en Estudios en homenaje al profesor José Szmolka Clares, Granada, Universidad, 2005, pp. 345-358.

Litvak, Lily, Latinos y anglosajones: orígenes de una polémica, Barcelona, Puvill, 1980.

—, El jardín de Aláh. Temas del exotismo musulmán en España (1880-1913), Granada, Don Quijote, 1985.

Lloréns, Vicente, El romanticismo español, Madrid, Castalia, 1989.

López, Bernabé, Orientalismo e ideología colonial en el arabismo español (1840-1917), Granada, Universidad, 2011. 
López, Pablo, Historia de la música española, Madrid, Alianza, 1983.

López-Casanova, Arcadio, El texto poético. Teoría y metodología, Salamanca, Colegio de España, 1994.

Martín, José Luis, "Reconquista y cruzada”, Studia Zamorensia, 3 (1996), p. 215-241.

Menéndez Pidal, Ramón, La epopeya castellana a través de la literatura española, Madrid, Espasa-Calpe, 1945.

Mínguez, José María, Historia de España. 2. Las sociedades feudales. 1. Antecedentes, formación y expansión (siglos VI al XIII), Madrid, Nerea, 1994.

Montgomery Watt, William, Historia de la España islámica, Madrid, Alianza, 1974.

Morales Lezcano, Víctor, Africanismo y orientalismo español en el siglo XIX, Madrid, UNED, 1988.

Mortelette, Yann, Histoire du Parnasse, París, Fayard, 2005.

Navas Ruiz, Ricardo, El romanticismo español. Historia y crítica, Salamanca, Anaya, 1973.

_ , "José Zorrilla, precursor: Visión lírica de Castilla y España", Castilla, 16 (1991), pp. 121 136.

Nebrija, Antonio, "Prólogo a la gramática de la lengua castellana", en Gramática de la lengua castellana, 1492. [https://www.ensayistas.org/antologia/XV/nebrija/]. Consulta: 29/01/2015.

Ochoa, Eugenio de, Tesoro de los romanceros y cancioneros españoles, históricos, caballerescos, moriscos y otros, París, Baudry, 1838.

Peinado, Rafael y José López de Coca, Historia de Granada. La época medieval, siglos VIII$X V$, Granada, Don Quijote, 1987.

Peña, Pedro de la, Antología de la poesía romántica de la lengua española, Madrid, Júcar, 1984.

Pérez-Reverte, Arturo, "Moros de la morería”, 31 de marzo (2014). [http://www.perezreverte.com/articulo/patentes-corso/908/moros-de-la-moreria/]. Consulta: 28/01/2015.

Ramírez, Ángel, Zorrilla, el más grande poeta de la raza, Madrid, Nuestra Raza, 1935.

Real Academia Española, Diccionario de la lengua española, 2014. [http://dle.rae. es/?w=diccionario]. Consulta: 03/02/2015.

Rodríguez Lesmes, Dacio (coord.), Zorrilla, poeta nacional (1893-1943). Homenaje de Palencia a sus cronista Oficial e Hijo Adoptativo en el cincuentenario de su muerte, Palencia, Delegación Provincial de la Vicesecretaría de Educación Popular, 1944.

Rodríguez Marín, Francisco, Zorrilla, comentador póstumo de sus biógrafos. Cartas íntimas e inéditas del gran poeta español (1883-1889), Madrid, Bermejo, 1934.

Rojas, José Pablo, El gato de sí mismo, de Uriel Quesada: Novela de la travestización literaria, tesis de maestría, San José, Universidad de Costa Rica, 2012.

Sadiq, Sabih, "La poesía árabe y los poetas españoles del siglo XIX. José Zorrilla (18291897)”, Miscelánea de estudios árabes y hebraicos. Sección árabe-islam, 45 (1996), pp. 281-294.

Said, Edward, Orientalismo, Madrid, Libertarias, 1990.

Sainz de Robles, Federico, Historia y antología de la poesía española (en lengua castellana) del siglo XII al XX, Madrid, Aguilar, 1950.

Sánchez-Albornoz, Claudio, España, un enigma histórico, Barcelona, Edhasa, 2001.

Sebold, Russell, “Zorrilla en sus 'Orientales': Sentido histórico y arte”, Ínsula, 564 (1993), pp. 1-2.

Seco de Lucena, Luis, Orígenes del orientalismo literario, Santander, Bedia, 1963.

Southern, Richard, Western Views of Islam in the Middle Ages, Cambridge: Harvard University Press, 1962. 
Torres Nebreda, Gregorio, “Introducción”, en Antología poética, Barcelona, Plaza y Janes, 1984, pp. 9-51.

Valera, Juan, Florilegio de poesías castellanas del siglo XIX, I, Madrid, Fernando Fe, 1902.

Van Aken, Mark, Pan-hispanism. Its Origin and Development to 1866, Barkeley-Los Ángeles, University of California Press, 1959.

Vernet, Juan, Lo que Europa debe al Islam de España, Barcelona, Acantilado, 1999.

Zorrilla, José, Obras, I, París, Garnier Hermanos, 1850.

-, Obras de José Zorrilla, I, París, Baudry, 1852.

—, Poesías escogidas de José Zorrilla, Madrid, Viuda de Hernando, 1894.

-, Obras completas, I, Madrid, Manuel Pedro Delgado, 1905.

—, Poesías de don José Zorrilla, Ed. Manuel P. Delgado, Madrid, Lagasca, 1917a.

-, Poesías, Valladolid, Castellana, 1917b.

—, Poesías, Ed. Narciso Alonso Cortés, Madrid, Ediciones de la lectura, 1925.

-, Obras completas, I, Ed. Narciso Alonso Cortés, Valladolid, Santarén, 1943.

-, Antología de poesías líricas, Sel. José María de Cossío, Buenos Aires-México, EspasaCalpe, 1946.

—, Poesías, Ed. Narciso Alonso Cortés, Madrid, Espasa-Calpe, 1965.

- Antología poética, Ed. Gregorio Torres Nebreda, Barcelona, Plaza y Janes, 1984.

_- Antología poética, Ed. Ricardo de la Fuente Ballesteros, Madrid, Espasa-Calpe, 1993a.

-, Flor de verso y prosa, Sel. Santiago de los Mozos, Valladolid, Ámbito, 1993b.

Zuleta, Enrique, España en América. Estudios sobre la historia de las ideas en Hispanoamérica, Buenos Aires, Confluencia, 2000. 
